\title{
IMPROVING STUDENTS' VOCABULARY BY USING MIMICRY MEMORIZATION METHOD
}

\author{
Evelyn C. Manoppo, Herling Rares, Jenie Posumah \\ English Education Department, Faculty of Language and Arts, Manado State University \\ Email : manoppoevelyn81@gmail.com
}

\begin{abstract}
The research is about improving the students' vocabulary by using Mimicry Memorization Method of eighth grade at SMP Berea Tondano. The purpose of this research is to find out the students' vocabulary improvement after teach by Mimicry Memorization Method. This research is quantitative research uses pre-experimental design with one group pre-test and pos-test. This study involves 18 students. The result of this study shows that the mean score of post-test $(63,61)$ is higher than score of pre-test $(55)$. The result of this research shows Mimicry Memorization Method is suitable to use in help the students to improve their vocabulary. English teacher suggests to apply Mimicry Memorization Method in order to help students to improve their vocabulary. The teacher should prepare the material well to get maximum result in teaching learning process. Teacher should create the condition of the class to be fun and livelier.
\end{abstract}

Key Words: Improving, vocabulary, mimicry memorization method.

\section{INTRODUCTION}

"Language is the most important aspect in the life of all human beings" (Panambunan E, Tulung G. J, \& Maru M. G. 2016:58). Vocabulary is one of the important aspects that must be mastered by the student before learning English. The acquisition of language, in one side, is surely determined by the acquisition of words. vocabulary is fundamental for understanding language and developing learner's English skills.

Mogea, T. (2019:9) states "English is an international language used all over the world, for education, technology, political, and commercial purpose." In Indonesia, English is declared as a foreign language. not a second language. It is due to most Indonesian speak local languages as tat home and Bahasa Indonesia as the second language. According to Hampp P. L. (2019:16) "English teaching should be introduced to Indonesian children early on". The teaching of English in Indonesian school starts from kindergarten to university. Most of teachers in Indonesia are using the traditional method of drilling and grammar translation. The classroom activities only focused on the activities on the textbook. In addition, teachers rarely use interesting media in teaching English. That is the reason why many students do not find the English class interesting.

Based on the preliminary, observation is conducted in SMP Berea Tondano, the students of eighth grade is lack of vocabulary. Based on that reason, 
the writers want to find out the applicable technique which can help students to improve their vocabulary skills. There are, some technique that can be uses to solve the problem but in this case the writers use Mimicry Memorization Method to improve students' vocabulary.

According to Nuha (2016:204-205) Mimicry Memorization Method is a method of teaching that way to imitate and memorize the target language. This method also known as informant-drill method. Memorization method is how to imitate and remember or memorize or a process of remembering something with memory power.

\section{Review of Literature}

\section{Vocabulary}

According to Lehr (2004: 1), vocabulary is knowledge of words and words meaning in both oral and print forms which are used in listening, speaking, reading, and writing. According to Mozes G. N, Liando N. V. F. (2019:28): "Since vocabulary is important in language learning, interesting activities and a good environment are needed to influence very young learners' brains and motivation to master them". Based on that statement above, vocabulary is all the words a person known and uses in a language that have meanings. Vocabulary is words meaning in both oral and print.

\section{Mastering Vocabulary}

Mastering vocabulary is especially English, because the potential knowledge that can be known about a word is rich and complex (Schmitt, 2000: 5). According to Tahrin A, Wowor D. J, \& Liando N. V. (2018:2), "In practice, vocabulary is difficult for students to comprehend. They feel so hard to memorize that because the teacher still use the old method for teaching it through only writing down on the white board and asked them to translate and memorize the words."

\section{Mimicry Memorization Method}

Mimicry memorization method begins with an initiation from a native speaker or recorded materials, the students are supposed to remember a large number of useful sentence or word within a particular situation, from the memorized sentences are drawn certain structures for further drills (Fauziati, 2002:05). According to Nuha (2016:204), mimicry memorization method is about imitate and memorize words. This method is also known as informant-drill method.

\section{RESEARCH METHODOLOGY}

This research uses quantitative research method. (Creswell 2008:6). The design of this research uses preexperimental with one group pre-test, treatment, and post-test design to know student's ability in vocabulary (Gay, 2006:257). There are two tests, $T_{1}$ as the pre-test and $\mathrm{T}_{2}$ as the post-test. $\mathrm{X}$ is use to symbolize the treatment. $\mathrm{N}$ uses to symbolize the group.

\section{important in learning language,}




\begin{tabular}{|c|c|c|c|}
\hline Group & $\begin{array}{c}\text { Pre- } \\
\text { test }\end{array}$ & Treatment & Post-test \\
\hline $\mathrm{N}$ & $\mathrm{T}_{1}$ & $\mathrm{X}$ & $\mathrm{T}_{2}$ \\
\hline
\end{tabular}

(Gay, 2006:257)

\section{Sample}

The sample of this research is eighth gradem consists of 18 students at SMP Berea Tondano.

\section{Data Analysis}

In analyze the obtain data, the writers use mean score formula. After finding the mean score, the result put into Frequency Distribution and Polygon Diagram. Mean score formula:

$\overline{\mathrm{X}}=\frac{\sum \mathrm{x}}{\mathrm{n}}$

Hatch and Farhady, (1982:30)

Where:

$$
\begin{array}{ll}
\overline{\mathrm{x}} & : \text { Mean score } \\
\mathrm{n} & : \text { Total score } \\
\sum \mathrm{x} & : \text { Number of students }
\end{array}
$$

\section{RESULT}

The sample of this research consists of 18 students of eight grade at SMP Berea Tondano. This research uses quantitative research through preexperimental design with one group pretest and post-test. To collect data, the writers use test in form of multiple choices question.

Table 1. Matrix of pre-test and post-

\begin{tabular}{|c|c|c|}
\hline 2 & 60 & 75 \\
\hline 3 & 55 & 60 \\
\hline 4 & 50 & 55 \\
\hline 5 & 65 & 75 \\
\hline 6 & 50 & 60 \\
\hline 7 & 65 & 70 \\
\hline 8 & 55 & 65 \\
\hline 9 & 45 & 50 \\
\hline 10 & 55 & 65 \\
\hline 11 & 60 & 70 \\
\hline 12 & 50 & 65 \\
\hline 13 & 40 & 55 \\
\hline 14 & 60 & 65 \\
\hline 15 & 55 & 60 \\
\hline 16 & 60 & 65 \\
\hline 17 & 50 & 55 \\
\hline 18 & 65 & 70 \\
\hline Total & 990 & 1145 \\
\hline
\end{tabular}
test

\begin{tabular}{|c|c|c|}
\hline $\begin{array}{c}\text { Students } \\
\text { Number }\end{array}$ & Pre-Test & Post Test \\
\hline 1 & 50 & 65 \\
\hline
\end{tabular}

The mean score of pre-test:

$$
\begin{aligned}
\bar{X} & =\frac{\sum X}{n} \\
& =\frac{990}{18} \\
& =55
\end{aligned}
$$

The mean score of the pre-test is 55. The achievement in the pre-test show us that from the 18 students who take part in the T1, the highest score is 65 and 
the lowest score is 40. It shows students' achievement in pre-test is lower.

The mean score of post-test:

$$
\begin{aligned}
\bar{X} & =\frac{\sum X}{n} \\
& =\frac{1145}{18} \\
& =63,61
\end{aligned}
$$

The mean score in post-test is 63,61. It shows that students' achievement is improved. The arrangement of achievement in the posttest show us that from the 18 students who take part in the test, there are 14 students who get good mark and then there are 4 students get better mark.

Table 2. Students gaining scores

\begin{tabular}{|c|c|c|l|}
\hline $\begin{array}{c}\text { Students } \\
\text { Number }\end{array}$ & $\begin{array}{c}\text { Pre- } \\
\text { test }\end{array}$ & $\begin{array}{c}\text { Post- } \\
\text { test }\end{array}$ & $\begin{array}{c}\text { Gain } \\
\text { score }\end{array}$ \\
\hline 1 & 50 & 65 & 15 \\
\hline 2 & 60 & 75 & 15 \\
\hline 3 & 55 & 60 & 5 \\
\hline 4 & 50 & 55 & 5 \\
\hline 5 & 65 & 75 & 10 \\
\hline 6 & 50 & 60 & 10 \\
\hline 7 & 65 & 70 & 5 \\
\hline 8 & 55 & 65 & 10 \\
\hline
\end{tabular}

\begin{tabular}{|l|l|l|l|}
\hline 9 & 45 & 50 & 5 \\
\hline 10 & 55 & 65 & 10 \\
\hline 11 & 60 & 70 & 10 \\
\hline 12 & 50 & 65 & 15 \\
\hline 13 & 40 & 55 & 5 \\
\hline 14 & 60 & 65 & 5 \\
\hline 15 & 55 & 60 & 5 \\
\hline 16 & 60 & 65 & 5 \\
\hline 17 & 50 & 55 & 5 \\
\hline 18 & 65 & 70 & 5 \\
\hline & $\mathbf{9 9 0}$ & $\mathbf{1 1 4 5}$ & \\
\hline
\end{tabular}

The data shows that there are 18 students take part in the test. 3 students get increase by 15 points, 5 students get increase by 10 points, 10 students get increase by 5 points.

Table 3. Frequency distribution matrix of Pre-test

\begin{tabular}{|c|c|c|c|}
\hline Scores & Tally & Freq & $\%$ \\
\hline 65 & III & 3 & $16,66 \%$ \\
\hline 60 & III & 4 & $22,22 \%$ \\
\hline 55 & IIII & 4 & $22,22 \%$ \\
\hline 50 & HI & 5 & $27,77 \%$ \\
\hline 45 & I & 1 & $5,55 \%$ \\
\hline 40 & I & 1 & $5,55 \%$ \\
\hline
\end{tabular}

Table 3 shows that, there are 3 students get 65 points or $16,66 \%, 4$ students get 60 or $22,22 \%, 4$ students get 55 or $22,22 \%, 5$ students get 50 or 
$27,77 \%$, 1 student get 45 or $5,55 \%, 1$ student get 40 or $5,55 \%$.

\section{Frequency Polygon of Pre-test}

The frequency distribution above shows that, 2 students get 75 or $11,11 \%, 3$ students get 70 or $16,66 \%, 6$ students get 65 or $33,33 \%, 3$ students get 60 or $16,66 \%, 3$ students get 55 or $16,66 \%, 1$ student get 50 or $5,55 \%$.

\section{Frequency Polygon of Post-test}

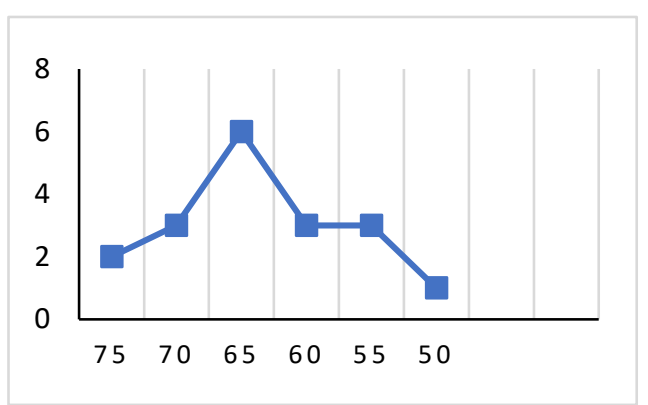

From 18 students, there are 2 students who get 75 score, 3 students get 70,6 students get 65,3 students get 60,3 students get 55 score, 1 student gets 50 .

Table 5. Recapitulation of mean scores of pre-test and post-test

\begin{tabular}{|c|c|}
\hline Test & Mean Score \\
\hline T1 & 55 \\
\hline T2 & 63,61 \\
\hline
\end{tabular}

\section{DISCUSSION}


After implementing the use of mimicry memorization method of eight grade at SMP Berea Tondano, the writers obtain the data of pre-test and post-test. The result shows the score of pre-test is lower than the score post-test. In other words, mimicry memorization method is effective in improving students' vocabulary. The result of pre-test that get by the writers show the mean score of the test is 55, it categorizes as poor. The score shows that from 18 students take part in pre-test, three students get score 65 or $16,66 \%$, four students get 60 or $22,22 \%$, four students get 55 or $22,22 \%$, five students get 50 or $27,77 \%$, one student get 45 or $5,55 \%$, one student get 40 or $5,55 \%$. When analyzing the score of pre-test, the writers find the students' problem, they do not know much vocabulary. According to Nuha (2016:204), Mimicry memorization method is about imitating and memorizing. This method is also known as informant-drill method. It means that mimicry memorization is method that use oral exercise and the teacher as the speaker. The learning process focus on memorize and pay attention to the teacher.

According to Fauzati (2002:05), Mimicry memorization method begins with an initiation from a native speaker or recorded materials, the students are supposed to remember a large number of useful sentence or word within a particular situation, from the memorized sentences are drawn certain structures for further drills. When doing the research, the writers give the material with use mimicry memorization method. The writers make sure students' vocabulary improvement by giving them a test to get score of post-test.
The result shows that the students' vocabulary is improve. It can be seen from the mean score of post-test is 63,61 . From 18 students who take part in post-test, two students get score 75 or $11,11 \%$, three students get 70 or $16,66 \%$, six students get 65 or $33,33 \%$, three students get 60 or $16,66 \%$, three students get 55 or $16,66 \%$, one student get 50 or 5,55 .

Based on the data above, it shows each student has their own vocabulary improvement. Based on the writers' experience, students need a method to support their achievement in learning material. It can be easier for students to understand the material well. The teacher should improve their skills in using method to help students in learning process, especially in this case using mimicry memorization method to improving students' vocabulary.

\section{CONCLUSION}

The result of this research shows that the score of the students in post-test are higher than the students' score in pretest. The mean score of pre-test is 55 while the mean score of post-test is 63,61. Therefore, the result of this research shows mimicry memorization method is suitable to use in help the students to improve their vocabulary.

\section{REFERENCES}

Aitchison, J. (2001). New Media Language. London and New York: Routledge.

Creswell, J. W. (2008). Educational Research . Ohio: Pearson education. 
E, F. (2002). Teaching of English as A Foreigner Language. Surakarta: Muhamadiyah University Press.

Gay, L. R. (2006). Education Research: Hell and Howell Company. Colombus, Canada: Pippin Publishing Limited.

Hampp, P. L. (2019). Use Of Songs In Teaching Simple To Be And Past Tense Teaching. Journal of English Language and Literature Teaching. Vol. 4 No. 1. http://ejournal.unima.ac.id/index .php/jellt/article/view/939

Hatch, E. a. (1982). Research Design and Statistic for Applied Linguistic. London: Rowley: new burry house.

Lehr, Fran. (2004). A Focus on Vocabulary is the Second Research-Based Practices. Available in http://www.prel.org./products/re /ES0419.htm. Retrieved on 07 January 2012.

Manurung, H. (2003). Mastering English Competence . Jakarta: Great Media.

Mogea, T. (2019). The Effectiveness of Question and Answer Technique in Teaching Reading Comprehension at SMP Negeri 3 Ratahan. Journal of Educational Method and Technology Vol. 2 No.2.

http://ejournal.unima.ac.id/index .php/jemtec.

Mozes G. N, Liando N. V. F. (2019). The Implementation of Phonic Method for Enhancing Very Young Learners' Vocabulary.
Advance in Social Science, Education and Humanities . Vol.438.

http://www.atlantispress.com/ proceedings/aes-19125940326

U, N. (2016). Ragam Metodologi dan Media Pembelajaran Bahasa Arab. Yogyakarta: Diva Press.

Panambunan E, Tulung G. J, \& Maru M. G. (2016). Improving Students' Speaking Ability Through Communication Language Teaching of The Second Level Students at 'MEC' Megalia English Course. Universitas Negeri Manado: Lembaga Penelitian Unima. http://ejounal.unima.ac.id/index. php/jellt/article/view/44/23.

Tahrin A, Wowor D. J, \& Liando N. V. (2018). Increasing Students' Vocabulary Through Mind Mapping Technique In Developing Students' Vocabulary Mastery at SMP Negeri 1 Remboken. Kompetensi Jurnal Ilmiah Bahasa dan Seni $\begin{array}{llll}\text { Vol. } & 5 & \text { No. } & \end{array}$ http://repository.unimaac.id/han dle/123456789/267 